Nadwa : Jurnal Pendidikan Islam

Vol. 14, No.1 (2020)

Accredited by Ristekdikti based on Decree No. 51/E/KPT/2017

DOI: $10.21580 /$ nw.2020.14.1.5766

\title{
Religious Moderation as a New Approach to Learning Islamic Religious Education in Schools
}

\section{Ulfatul Husna}

Universitas Islam Negeri Sunan Ampel Surabaya

ulfatulhusna@gmail.com

Muhammad Thohir

Universitas Islam Negeri Sunan Ampel Surabaya

muhammadthohir@uinsby.ac.id

\begin{abstract}
Islam as a religion with a slogan that brings grace to the universe, however historically not all religious articulations are compatible. One example is extreme attitudes in religion. The most important element in realizing the peace mission in schools is learning Islamic Religious Education (PAI). This study was conducted to reveal how to maintain religious moderation in schools in preventing extremism. This field study at SMA Negeri 1 (Senior High School) Krembung, East Java, Indonesia uses a qualitative descriptive method. The results showed that school moderation uses three main principles, namely tawassuth (middle); ta'adul (fair); and tawazun (balanced) principles are able to create a moderate situation, create a school of peace, progress, and form a generation with moderate views.
\end{abstract}

Keywords: Moderation; Schools in Indonesia; Islamic education; Extremism;

\section{Abstrak}

Islam sebagai agama dengan semboyan pembawa rahmat bagi alam semesta, namun secara historis tidak semua artikulasi agama itu cocok. Salah satu contohnya adalah sikap ekstrim dalam beragama. Elemen terpenting dalam mewujudkan misi perdamaian tersebut di sekolah adalah pembelajaran Pendidikan Agama Islam (PAI). Studi ini dilakukan untuk mengungkap bagaimana mempertahankan moderasi beragama di sekolah dalam mencegah ekstrimisme. Studi lapangan di SMA Negeri 1 Krembung, Jawa Timur, Indonesia ini menggunakan metode deskriptif kualitatif. Hasil penelitian menunjukkan bahwa moderasi beragama sekolah menggunakan tiga prinsip utama yaitu tawassuth, ta'adul dan tawazun. Prinsip-prinsip ini mampu menciptakan situasi yang moderat dan mewujudkan sekolah damai, berkemajuan dan membentuk generasi yang berpandangan moderat.

Kata kunci: Moderasi; Sekolah di Indonesia; Pendidikan agama islam;

Ekstremisme; tawassuth; ta'adul; tawazun. 


\section{Introduction}

The millennial era forces all sector to innovate in order can maintain its existence. Including in the field of education, the birth of the millennia generation that has already connected to technology from birth to complement the changing times.Teachers of Islamic Religious Education in this era of industrial revolution 4.0 disruption have complex challenges apart from meeting academic and social demands, they must also be able to keep up with rapid technological developments. Indonesia will experience a demographic bonus in 2030 that has the potential to become one of the nation's instruments of progress. 1 The main actors at that time were the younger generation who currently sits in high school and the first semester students at tertiary institutions. Therefore they need to be prepared into a generation that is not only intelligent, but also spiritually and socially. Islamic Religious Education teachers in this case have a complex role in galvanizing morally and mentally, including being able to present religion comprehensively to students, to prepare them to become human beings who are not only spiritually pious but also socially pious.

Teenagers in high school according to the theory of psychoanalysis is a period of looking for identity with doubt the concepts they get from childhood, including religious beliefs. 2 Therefore, the Islamic Religious Education teacher at this level must be able to present the true Islamic concept that carries the mission of rahmatan li al 'alamin, not extreme left or right. Islam taught by the Prophet, which is able to bring peace to themselves

1 Kementerian PPN/Bappenas, Bonus Demografi 2030-2040 : Strategi Indonesia Terkait Ketenagakerjaan dan Pendidikan, Siaran Pers, OECD, 2017, file PDF

2 Henri Saputro, The Counseling Way catatan tentang Konsepsi dan Ketrampilan Konseling, Deepublish, Yokyakarta, $2018: 48$. 
and the people around. It is not Islam whose presence is actually unsettling and frightening to those around him. Such an Islamic concept is Islam wasathiyah or moderate Islam. It is a moderate religion, if thoughts and behaviors are based on whatever has been practiced by the Messenger of Allah. Therefore he became the best example for all Muslims. A very polite temper that can make everyone respect and acknowledge his virtue, even though that person really hates him. 3

The development of Islam on the one hand is growing, but on the other hand the radicalism movement also sponsors resistance to Islam. This needs the full attention of Islamic religious teachers and all stakeholders in the world of education in order to suppress the growth rate of radicalism. If it does not get special attention from Islamic Religious Education teachers who collaborate with all school stakeholders, it is very dangerous for the integrity of the Unitary Republic of Indonesia, because in the future in the hands of these students, the fate of the government will be taken in what direction. While educational institutions act as instruments for the development of human resources in the future. 4 If it is mismanaged, this nation will bear enormous losses in the future. The phenomenon of extremism is also the author encountered from observations while teaching in SMA Negeri 1 Krembung, some students have a tendency towards fanaticism and extremism. They argued about the "necessity" to have niqob and jihad fi sabilillah, prohibition of Islam, as well as a firm attitude and refused to be led by nonMuslims.

3 Muhibbin, Hakekat moderasi beragama, Moderasi Beragama dari Indonesia untuk Dunia, LKiS, Yogyakarta, 2019 : 106.

4 Nur Syam, Islam Nusantara Berkemajuan, Tantangan dan Upaya Moderasi Beragama, Fatwa Publishing, Semarang,2018:107. 
Then the strengthening of religious moderation becomes very important to be instilled in students, as a solution to stem extreme understanding as well as manifestation of the National Mental Revolution Movement (GNRM) embodied in Strengthening Character Education (PPK) as mandated by Permendikbud number 20 of 2018, among which are religious characters and nationalism. These two characters are directly proportional to religious moderation, which is always preached by the two largest Islamic organizations in Indonesia, namely Nahdhatul Ulama $(\mathrm{NU})$, and Muhammadiyah.

\section{Method}

The method used is descriptive-qualitative case study approach, using the umbrella paradigm of phenomenology, focusing on one object namely religious moderation in SMA Negeri 1 Krembung, East java, Indonesia a case studied in depth so as to be able to uncover the reality behind the phenomenon. Huberman and Miles suggest that qualitative research data analysis is a process of reviewing, sorting data grouping with the aim of compiling work hypotheses and elevating them into theoretical research results.5 Analysis begins with data reduction, data display and data verification on strategies to strengthen religious moderation, religious reality and the implementation and implications of religious moderation, using social psychological theories and sociology-humanities.

\section{The Concept of Moderation Religion}

Moderation is often referred to as wasathiyyah and is confronted with the terms liberalism, radicalism, extremism and

5 Lihat dalam Matthew B. Miles \& AS. Michael Huberman, Analisis Data Kualitatif terj. Tjetjep Rohendi Rohidi, Jakarta: UI Press, 1992 :14. 
puritanism. Moderation if interpreted in language, according to the big Indonesian Dictionary means the reduction of violence and the avoidance of extremism.6 M. Quraish Shihab called the meaning of moderation in line with wasathiyyah although not exactly the same.7 The terminology of the wasathiyyah itself is actually purely derived from Islam itself which is wasathic, that is, all of its teachings have a characteristic of moderation, therefore followers must be moderate. Moderate in his beliefs and views, thoughts and feelings, and attachments. 8 Yusuf alQardawy mentions a number of vocabularies that are commensurate with the word wasathiyyah namely Tawazun, I'tidal, ta'adul and Istiqomah. Meanwhile, according to Khaled abu el Fadl wasathiyyah is the understanding that takes the middle way, namely understanding that is neither extreme to the right nor extreme to the left. Abdurrahman Wahid also formulated that moderation encourages efforts to realize social justice which in religion is known as al-maslahah al-'ammah.9

Wasathiyyah is a balance between ukhrawi and worldly life, souls and bodies, aql and naql, individuals and society, ideas and reality, religion and the State, old and new, religion and science, modernity and tradition, which are accompanied by the principle of "not lacking and excessive ". The word wasath is mentioned several times in the Qur'an and they all have a middle meaning or are between two ends.10 Among them are in QS.al Baqarah (2);

6 Kemdikbud., KBBI, https://kbbi.kemdikbud.go.id/moderasi, diakses pada tanggal 14 Maret 2020

7 M.Quraish Shihab, Wasathiyyah : wawasan Islam tentang moderasi beragama, Lentera Hati, Tangerang, $2019: 2$.

8 Shihab, Wasathiyyah : wawasan Islam ... 3.

9 Zuhairi Misrawi, Hadratussyaikh Hasyim Asy'ari Moderasi, Keutamaan, dan Kebangsaan, Jakarta: PT Kompas Media Nusantara, 2010 : 13.

10 Shihab, Wasathiyyah : wawasan Islam ... 43. 
this verse makes the position of the wasath in a high place. People in that position can best see the people below, and those below can see it too. This situation is illustrated by Ali Jumu'ah, like a person on a hill, if from the valley to the top of the mountain is approximately equal to the distance from the top of the mountain to another valley behind the mountain, then the person standing on the mountain can also be said to be in the wasath position, which is in the middle of the mountain.11 Being between the extreme left and extreme right, it is indeed not easy, when standing near the right, it will be claimed as fundamentalistconservative, when standing near the left position, it will be claimed as liberal.12

Ammar Sukri and Yusuf Qardawy as quoted by Afifuddin Muhajir equate wasathiyyah with three things that are the main characteristics of Islam, namely: 1) tawassuth (middle); 2) ta'adul (fair); and 3) tawazun (balanced). Then the three phrases are then put together in the term "wasathiyyah" or in other languages moderation. 13

Religion teaches about theology and also values that are in accordance with the essence of humanity. It means to wisely introduce who created it, how to worship the creator and then the values can be implemented into social life. Religion becomes the last pillar in solving problems faced by mankind, both social, cultural, political and religious issues themselves. So it is not surprising that political problems often escalate into theological

\footnotetext{
11 Ali Jumu'ah, Islam Wasathiyyah, https://www.wasathiyyah.com/karya/opini/23/01/2019/wasathiyyah-apamaksudnya/, diakses tanggal 16 Desember pukul 15.42

12 Hilmy, Masdar. "Jalan Demokrasi Kita.",Intrans Publishing, Malang, $2016: 43$

13 Afifuddin Muhajir, Membangun Nalar Islam Moderat : kajian metodologis, Tanwirul Afkar, Situbondo, $2018: 24$.
} 
problems.14 Likewise what happened to the Islamic Ummah so that it becomes compartmentalized in various groups. First the group of Muslims who have extreme tendencies, fundamentalists, and conservatives, and impose their understanding in the midst of Muslim society, sometimes even using violent means, call it salafi-wahabi. The other two tendencies are also extreme with adaptive attitudes toward negative non-Islamic or Western cultural changes, for example the Liberal Islamic Network (JIL). Such extreme attitudes have historically been motivated by political problems and are also caused by mistakes in understanding Islam, or their shallow knowledge of Islam, giving birth to actions that are contrary to Islamic teachings.

In this discussion the focus of religious moderation in the frame of Islamic Religious Education (PAI) as a main component of moral and character education in schools. How does PAI play its role in responding to the challenges of extremism which is currently increasingly globalized. The initial assumption of field research in SMA Negeri 1 Krembung is that religious moderation is an appropriate alternative approach to stem the growth rate of extremism which has begun to descend a lot on millennial generation. So to photograph how religious moderation and PAI are able to face the challenges of extremism, use three concepts of religious moderation, namely: Non-violent ideology in conveying religious teachings, adoption of modern values in learning, and practice of religion with contextual comprehension. 15

14 Harun Nasution, Teologi Islam : aliran-aliran sejarah analisa perbandingan, Universitas Indonesia, Jakarta, $2013: 3$.

15 Masdar Hilmy, Cetak Biru Moderasi Beragama : Urgensi Panduan Normatif Aplikatif, Moderasi Beragama, dari Indonesia untuk Dunia, LKiS, Yogyakarta, $2019: 404$. 


\section{Non-violent ideology in conveying Islamic teachings}

Religious moderation is between the extreme right and left, or in other words not extreme. So to find out whether a person is moderate or not, it can be seen from the opposite direction, which is extreme. The extreme attitude appears in various forms, including rude words, such as excessive curses, lies, and the spread of negative news, can also be excessive praise. Someone who is extremist usually rejects the presence of anything and anyone who is different from him, trying to get rid of him, and in turn will disbelieve and violence against him.16 The old myth that believes that the victory of a religious group must be paid in defeat by another group must end. The religious spirit must be transformed from a spirit of shortness and heroism (which encourages violence) to a spirit / work ethic and creativity (which encourages productivity). 17

Non-violent sufistic approach is the approach taken by Islamic leaders in teaching religion. Some studies say that Nusantara Islam is dominated by Sufistic Islam not only from domestic scientists, but also agreed by foreign experts, one of which is a theory from A.H. Johns, who said that Islam in the archipelago was more Sufistic. From there, was born great Sufi figures such as Nuruddin ar-Raniri, Hamzah Fansuri, Abd arRauf as-Sinkili, Muhammad Yusuf al-Maqassari, and a number of Wali Songo figures in Java.18

Islamic Religious Education that uses the Sufistic approach has the aim of longing for a harmonious community, nation and

16 Shihab, Wasathiyyah, ... 43.

17 Yudi Latif, Negara Paripurna, Historisitas, Rasionalitas, dan Aktualitas Pancasila, PT Gramedia Pustaka Utama, Jakarta, 2012 : 118.

18 Madarzuki Wahid dan Rumi, Fiqh Madzhab Negara: Kritik atas Politik Hukum Islam di Indonesia, Yogyakarta, LKiS, 2011 :100. 
state life. 19 The output of Sufistic Islamic education is the realization and externalization of Islamic peaceful teachings, marked by the ability to live in harmony and side by side with other people of different religions, different ideologies, different ethnicities, and different cultures. Because, differences are natural laws (sunnatullah) as Tajalli Allah SWT, which cannot be separated in everyday life.20 Islamic Sufism invites the salik to accept this difference as tajalli or manifestation of all the beauty of the nature and asthma of Allah SWT. 21 While the characteristics of a moderate attitude is to have the character of wasath (middle) between firmness and flexibility, a moderate person will be polite and avoid violence. 22

\section{Adoption of Modern Values (Technology, Democracy, Human Rights) in Islamic Learning}

Indonesia is not a secular state that separates religion and state affairs, and is also not a religious state that eliminates democratic (modern) values such as the Islamic State.23 So the moderate attitude in religion has the characteristic of being able to adopt modern values, so it is not stagnant and old-fashioned.24 Because after all the processes and phenomena of globalization

19 A.Gani, Pendekatan Sufistik dalam Pendidikan Islam Berwawasan Perdamaian, Akademika, Vol.23, 2018 : 393.

20 Said Aqil Siroj, Tasawuf Sebagai Kritik Sosial: Mengedepankan Islam sebagai Inspirasi bukan Aspirasi, Bandung, Mizan :2006 : 35

21 Muhammad Nawawi al-Bantani, al-Futuhat al-Madaniyyah , (T.Th.), t.t., $21-22$.

22 Suwardi Endraswara, Mistik Kejawen, Sinkretisme, Simbollisme dan Sufisme dalam Budaya Spiritual Jawa, Narasi, Jogyakarta, 2003 : 38-39.

23 Zainiyati, Husniyatus Salamah. "Learning Design of Citizenship Education in Indonesia after Ahok Tragedy, A Shaep of Social Media and Critical Literacy in Educational Process." Tarbuyatuna : JurnalPendidikan Islam, 2018: 52-71.

24 Endraswara, Mistik Kejawen, ... 38-39. 
have a very significant influence on the development of religious values, where diversity blends with modernity. Whereas in the moderate paradigm, globalization is not only negatively charged, but there is also a positive side that can be exploited, even cannot be dammed or rejected. 25 This paradigm emphasizes the importance of the substance of the values and teachings of religion itself. The practical involvement of religion in the state must not spoil the noble values contained in religion, because religion will become a place for politicization and contestation.

The attitude exemplified by the prophet Muhammad. is an attitude of surrender to God, not something else, and requires an open, just and democratic social order. Democratic attitude and upholding human rights (HAM) in Islam is the equality of human dignity before God and the prohibition of coercion of will / views among humans. even an apostle gets only the task of telling the truth, not imposing the truth on humanity. So the arrangement of life by creating absolute power in fellow human beings is an unjust and uncivilized attitude. 26

In addition to democratic values and human rights, adopting contemporary learning models along with the development of science and technology in the learning of Islamic Education, becomes a necessity. PAI must be able to transform knowledge into attitudes and practices in real life. The application of the rule "Al muhafadzatu 'ala qadimi al shalih wa al akhdu bi al jadidi al ashlah "is appropriate when applied in learning. 27 Maintain classical learning models that are still relevant, and apply learning modes according to 21 st or $4 \mathrm{C}$ (Critical Thinking, Creative,

25 Salamah, Islam dan tantangan Globalisasi : berbagai Paradigma Islam dalam menghadapi Globalisasi, Humanistika, 2019 : 51.

26 Latif, Negara Paripurna, ... 390.

27 Ahmad baso, Islam Nusantara, Ijtihad Jenius \& Ijma' Ulama Indonesia Jilid I, Pustaka Afid, Tangerang Selatan, 2019 :1003. 
Communicative and Collaborative) skills, literative. Implement Strengthening Character Education (PPK) which contains 16 characters as the application of the values of Pancasila which are summarized in 5 (five) interrelated main values namely religiosity, nationalism, independence, mutual cooperation, and integrity. 28

\section{Practicing Religion with Contextual Understanding}

Contextual understanding of the text becomes a necessity, as well as valid with the reasons: a) people who lived in the time of the Prophet. a completely empty environment of cultural institutions which are not all denied by the presence of texts (texts) which cause some of them to be typical Arabic. b) textual understanding of text implementation is often not in line with the benefit which is precisely the presence of Islam itself, namely "Islam rahmatan lil 'alamin". c) Contextualization of understanding of Islamic texts implies that society wherever and whenever it is located, is always seen as positive-optimistic by Islam as evidenced by its distinctive attitude that is accommodating to existing social institutions (containing benefits) 29 formulated by the method "Al muhafadzatu 'ala qadimi al shalih wa al akhdu bi al jadidi al ashlah "caring for and preserving tradition and disseminating tradition. To put it simply, maybe the study of fiqh and the science of tools, but do not forget the ideas of our country that appear to color these two sciences, for example the matter of rice zakat, and so forth. 30

Islamic boarding school education always emphasizes the ushul fiqh and qawa'idul fiqhi approaches in looking at problems,

28 Kemdikbud, Permendikbud No.20 Penguatan Pendidikan karakter pada SatuanPendidikan Formal, 2018

29 Hilmy, Cetak Biru Moderasi Beragama ... 404.

30 Baso, Islam Nusantara, ... 103. 
most of which are not merely textual, meaning more to the contextual approach (zhurufi-mashlahi). The combination of the two approaches can be a model in promoting a moderate view because the contextual approach will be closely related to various considerations in accommodating various differences that exist in the midst of society. Like the method of da'wah with gamelan performed by Sunan Kalijaga, for example, which is then continued by Islamic boarding school scholars, always basing on maqashid asy shari'ah for the achievement of a religious teaching understood by the people.31 When a group of people shout to enforce the law of Allah, the syari'at for the price of death, the sunnah for the Prophet for the price of death, return to the Koran and Hadith, they are right and not wrong. However, what is important to note is that in religious teaching, one cannot only see the future of the framework without paying attention to the left and the right which will eventually get caught up in conflict because all parties feel the most righteous and the most Islamic. Thinking wisely in building a moderation framework to strengthen the social spirit of the younger generation is very important.

Learning to understand and accept differences without having to be confused about differences is an attitude that can be strengthened so that they understand more about the realities of life in togetherness, which ultimately is to strengthen tolerance. But what is important to note is that in teaching religion, one cannot only see the future of the skeleton without regard to the right and left, which in the end will be trapped in conflict because all parties feel the most righteous and most Islamic. 32

31 Baso, Islam Nusantara, ...115.

32 Baso, Islam Nusantara, ...116. 


\section{Religious moderation in SMAN 1 Krembung}

After obtaining data from the field, then it is reduced and categorized according to the focus of the study on three things, namely:

Table of Strengthening Religious Moderation in SMAN 1 Krembung

\begin{tabular}{|c|c|c|}
\hline No & Category & Result \\
\hline 1 & $\begin{array}{l}\text { Strategy for } \\
\text { strengthening } \\
\text { religious } \\
\text { moderation }\end{array}$ & 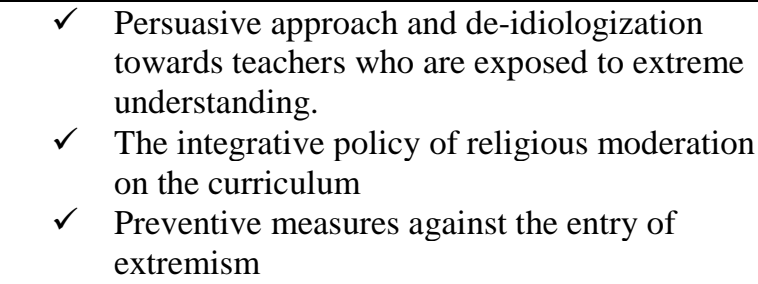 \\
\hline 2 & Religious reality & $\begin{array}{l}\checkmark \text { The number of teachers is } 66 \text { people and } \\
\text { employees are 18, 100\% are Muslim } \\
\checkmark \\
\text { The number of students is 1221, consisting } \\
\text { of: 2 Catholic children, 10 Protestant children } \\
\text { and 1 Hindu child, and 1208 Muslim students } \\
\checkmark \quad \text { Total citizens of SMA Negeri 1 Krembung } \\
\text { who are Muslim 99.03\% } \\
\checkmark \quad \text { The majority of Muslim backgrounds are } \\
\text { ahlussunnah wal jama'ah } \\
\checkmark \quad \text { Positioning the issue of khilafiyyah fiqhiyyah } \\
\checkmark \text { ijtihadi to the Qath'i region. } \\
\text { Understanding Islam textually, so teachers } \\
\text { tend to be rigid, and hard in applying the } \\
\text { rules, without considering the psychological } \\
\text { and social impacts. } \\
\checkmark \quad \begin{array}{l}\text { Ghuluw (excessive) attitude in religion that } \\
\text { triggers the emergence of fanaticism. }\end{array}\end{array}$ \\
\hline 3 & $\begin{array}{l}\text { Implementation } \\
\text { of moderation } \\
\text { and the } \\
\text { implications of }\end{array}$ & $\begin{array}{l}\checkmark \text { Salim culture, istighotsah, yasinan, diba'an } \\
\text { (maulidu al diba '), ngaji kitab, rotibul haddad, } \\
\text { tahlilan and so forth. }\end{array}$ \\
\hline
\end{tabular}


religious

moderation $\checkmark$ There is one teacher and several students who reject religious culture at school, and consider bid'ah even forbidding it.

$\checkmark$ Excessive religious attitude, so that other people who disagree with it are considered less religious.

$\checkmark$ Teaching religion tends to be dogmatic, without giving space to think and find truth.

$\checkmark$ Islamic religious education is only normative in nature and uses a revelation approach only, without considering empirical studies and anthropological sociological analysis.

\section{Discussion}

\section{The PAI approach of Moderation}

Realizing the ministry of religion's program to stabilize diversity by instilling Islamic moderation through the internationalization of learning activities in the classroom is a must for PAI teachers. The material content includes five aspects, namely aspects of the Qur'an, aspects of Aqeedah, aspects of Figh, aspects of morality, and aspects of dates. All materials are based on KD in accordance with Ministry of Education and Culture. No.37 of 2018. Then the learning material integrated with Islamic values of wasathiyyah, "tawassuth, ta'adul, and tawazzun", is presented using critical and contextual learning strategies, so as to be able to instill an understanding of religion that is not only dogmatic- only doctrinaire. However, able to transform the values of wasathiyyah in daily life through the attitude of accepting differences, diversity in khilafiyah issues in the teachings of Islam. And of course the tolerant attitude is not only for fellow Muslims, but also accepts and tolerates the differences of the followers of other religions in schools, by respecting them to practice their religion. This means connecting religious teachings with the context of Unity in Diversity, through 
ta'adul values in religious moderation must be manifested in everyday attitudes, not just understood.

Sensitivity to the socio-cultural context in applying learning models in the classroom is needed. Because if not, learning is only normative, and will dry up empirical values. The culture of Indonesian society which is known for its main characteristics of mutual cooperation, is very appropriate when cooperative learning is applied, which emphasizes cooperation. This learning model as well as a moderate attitude of learning that is individualistic and competitive with traditional approaches that position the teacher as the center of learning, and ultimately will place what is conveyed by the teacher as an absolute truth.

Thus students gain religious knowledge limited to memorizing, and only think dogmatically and in black and white and have a dogmatic, black-and-white, halal-haram, right-wrong, and no-space mindset that makes something for dialogue. 33 So that space of right and wrong becomes narrow and truth becomes absolute. Conversely, if the truth space is wide, then when something that is believed is true, it still gives an opportunity for the belief of others is also true. Because absolute truth only belongs to God.34 Such thinking, which will bring progress or tajdid Islam, Islam that is able to respond to the progress of the times.

\section{Typology of Extremism in PAI learning}

There are three typologies of PAI learning practices when linked to the approach of normative Islamic studies according to

33 TGS. Saidurrahman, Penguatan Moderasi Islam Indonesia dan peranPTKIN, , Moderasi Beragama dari Indonesia untuk Dunia, (LKiS, Yogyakarta, $2019: 35-37$ 
Charles J. Adams.35 First: the missionary-traditionalist approach, which is the approach used to carry out the mission of Islamizing non-Muslims. Or in a smaller scope is to Islamize the understanding and behavior of the Islamic version or the same as himself or his group. A person who uses that approach in Islamic studies, always assumes that his religious understanding is the most correct, so he does not want to accept the opinions of others who disagree with him (exclusive).

In fact, it is not uncommon that the news he conveys contains expressions of hatred towards other groups. Second: the apologetic approach, which is an approach using the understanding of religion based on historical romanticism and the tendency of Muslims to succeed. So as to understand the teachings of Islam with the aim to defend themselves and not scientific goals. An educator who uses this approach in conveying Islamic teachings, tends to impose the will on his students, how can his teachings be absorbed and followed by students, as he was when he was a student first.

The attitude of apology can then bring out the identity of a teacher who is successful in changing their students. Third: An irrational approach is an approach with an effort to understand the understanding of religion outside of himself as a sympathetic effort and in order to understand the beliefs of others. However, by using this approach, it is trapped in the problem of people outside who are not the same as him, must be the same as the religious beliefs adopted by him or his group.

According to the religious sociologist Joachim Wach, the social background of the preacher, in this context is the teacher of religious education, determines the initial characteristics of

35 Ahwan Fanani dan Tholhatul choir, ed. Islam dalam Berbagai Pembacaan Kontemporer, Pustaka Pelajar, Yogyakarta, 2009 : 277-278. 
religious formation in schools. Because the influence of society on religion is as strong as the influence of religion on society. 36 While the environment is also very influential on society to do something that violates their nature, for example radicalism. 37 Moreover, the flow of radical systemic contents in school lessons or curricula is increasingly complex due to non-selective globalism. 38 A teacher who has a strict educational background in shaping discipline, then he will apply the same way to his students, because it is considered as the most effective method in education. So that all forms of violence, in the name of discipline and for the success of students. He did not realize that it was merely to maintain his existence as a student / student who had succeeded, so that he became a disciplined and dedicated teacher.

The three typologies have the potential to be extreme because they have excessive tendencies, making it difficult to position themselves in wasaths. But of course in determining something is excessive or not, ghuluw or tatharruf (extreme) must be careful not to base it on personal judgment, but instead use the perspective of religious teachings. For example, a person since childhood was educated in a boarding school, so accustomed to memorizing the arguments and reading the yellow book, and consider other people who do not like themselves less religious knowledge. Vice versa, judging someone who practices a good

36Syamsuddin Abdullah, Agama dan masyarakat, pendekatan Sosiologi Agama, Logos Wacana Ilmu, Ciputat, 1997 : 94.

37 Arsip Widodo, "Moderation Of Islamic Education As An Effort To Prevent Radicalism (Case Study of FKUB Singkawang City, Kalimantan, Indonesia," Nadwa : Jurnal Pendidikan Islam, 13 (2), 2019. DOI : 10.21580/nw.2019.13.2.5086

38 Muhammad Thohir. "Radikalisme Versus Pendidikan Agama Menggali Akar Radikalisme dari Kekerasan Terhadap Anak Atas Nama Pendidikan Agama." Nadwa: Jurnal Pendidikan Islam, ( (2), 2015: 181. http://dx.doi.org/10.21580/nw.2015.9.2.521 


\section{6 | Ulfatul Husna \& Muhammad Thohir}

religion, and syar'i dress, even though justified by religion is considered as someone who is extreme.39 This paradigm of thinking needs to be reconstructed, so that the extreme does not only belong to certain organizations, but someone in the circle of moderate organizations also has the potential to be extreme.

\section{Moderation between exoteric and esoteric}

Islam as a complete system of religious teachings, gives place to two types of religious appreciation, namely: First exoteric (Dhahiri), namely religious appreciation oriented to fiqhiyah formalities or to strict religious norms and rules. Second: esoteric (Bathini), which is religiously oriented and focuses on the core religious and religious goals. So emphasizing on one of the aspects of such an existence will cause an imbalance that violates the principle of religious moderation, tawazun.40 Globalization is often used to mark the pace of modernization which is accelerating, radical and powerful, and has an extraordinary influence on the shifting of religious values.41 The shift in religious values followed by religious attitudes is clearly visible in this globalization era. Where diversity is integrated with modernity, diversity is more to be publicized than lived and contemplated. While among the religuises, there are not a few Muslims who point to dzahiri, or are called the shari'ah (scripturalists) or fundamentalists. Many also only refer to the heart, or called the Thoriqah (Sufi). 42

39 Shihab, Wasathiyyah, ... 114-115.

40 Dadang Kahmad, Sosiologi Agama, Remaja Rosdakarya, Bandung, cet. Ke-5 $2009: 200$.

41 Faisal Islamil, NU Moderatisme dan Pluralisme, konstelasi dinamis keagamaan, kemasyarakatan dan keagamaan, IRCiSoD, Yogyakarta, 2020 : 65 .

42 Kahmad, Sosiologi Agama... 201. 
The essence of Islamic learning is on the formation of moral or noble character, then the presence of Islamic learning in schools must always be strived to balance (tawazzun) between the needs of reason (science) and heart (faith and devotion), the need for dzahiri and bathini, between cognitive and psychomotor. In line with the four pillars of UNESCO's education, namely learning to know, learning to do, learning to be, and learning to live together. Education is not only limited to the transfer of knowledge in the sense of being trapped in the text, so the practice of learning PAI is only at the stage of memorizing text without regard to the existing context. But it is also a transfer of value so that it can expose individuals to the values implicit in human rights, democratic principles, understanding and respect for intercultural and peace in all walks of life and human relations to enable individuals and communities to live in peace and harmony.

According to Thomas Lickona, an expert in character education, in instilling good character, there are ten values of the essence of virtue (The Golden Role) of which is justice, which is respecting the rights of all people. 43 The rights referred to here are the rights of students in adhering to their beliefs / religions. Justice (ta'adul) is what directs one to treat others as he wants to be treated by others, is the principle of justice in cultures and religions throughout the world. In Islamic teachings, the famous hadith of the Messenger of Allah. which means: "do not believe among you so that you can love your brother as you love yourself". These values are in the main values of moderation, namely tawassuth, ta'adul, and tawazzun, which contain noble character values, and become a necessity to be applied in strengthening character education.

43 Thomas Lickona, Character Matters, Persoalan Karakter Bagaimana Membantu Anak Mengembangkan Penilaian yang Baik, Integritas, dan Kebajikan Penting Lainnya, Bumi aksara, Jakarta, 2016 : 16-17. 
Islam teaches so many noble characters, even putting morals in the main position, until the perfection of one's faith is seen from the good character he has. One of the teachings is the suggestion to respect the older and to love the younger. But parents are often trapped in the first context, namely as a parent or teacher who must be respected by their children or students. So that when this is not the case, he will be angry and say harsh words, under the pretext of teaching the child, which due to that attitude leaves psychological trauma to the child. Religious education which moderates the exoteric and esoteric aspects, is able to embody the mission of the rahmatan lil 'alamin religion and realize a democratic, just and tolerant life.

\section{The Urgency of Religious Moderation in Schools}

Textual understanding of religion and positioning of the branches of religion in the main areas of religious teachings often lead to debate. And the area of ijtihadiyyah fiqhiyyah which is always dynamic, is positioned as a region of religious principles that must not change. Limited religious knowledge and narrow normative reasoning provide reinforcement for the justification of extreme behavior in schools. Including understanding of the meaning of jihad to combat non-Muslims who in their designation "infidels". This extreme and textual religious interpretation has implications for religious behavior that cannot accept diversity and is far from the value of Islamic moderation taught by the Prophet. Awareness in heterogeneity cannot be constructed properly, for individuals who have never felt in direct contact with diversity in religion. So that the practice of democracy is constrained by the fact of diversity and the assumption that the competitor is right then obsessed with making others like him. Whereas democratic values, pluralism, human rights, tolerance, 
the principle of gender equality, the building of civil society, are actually in accordance with the authentic teachings of Islam.

The principal's policy strategy and the efforts of PAI teachers in SMA Negeri 1 Krembung in strengthening religious moderation, have implications for; a) the emergence of an extreme understanding of teacher awareness to no longer indoctrinate students to follow their understanding. The strategy taken by the school principal by using the persuasion approach had implications for the reduction in anti-Pancasila attitudes, antirespect for flags and extreme religious teachings towards students by one of the teachers in SMA Negeri 1 Krembung. Although until now the teacher has not been able to accept the religious traditions that exist in Krembung. b) High School, but at least he is aware of how to respect differences, although he still occasionally slips his religious understanding into students when he teaches. c) The emergence of mutual respect for each other, namely the tolerance of fellow students and students with the teacher. d) The emergence of students' moderate attitudes in realizing peaceful relations between people, religion in diversity and e) The ability of students to accept and reject information that leads to extremism-fundamentalism and exclusivity in schools. f) Students are able to filter which information should be received and not, which lessons can be taken or not.

\section{Conclusion}

Religious extremism is caused by several factors: first, incomplete understanding of religion. Second, learning religion with the wrong teacher (having a narrow / strict understanding of religion). Third, mistake is the use of approach in teaching religion, in the normative approach to Islamic studies it is called "the missionary traditionalist, apologetic, and irenic approach. The four claims to themselves as someone who has understood, 
possessed, even carried out purely and consistently the values of absolute truth. By holding on to the main values of wasathiyyah, namely tawassuth, ta'adul, and tawazzun, the school will be able to avoid being caught in extremism-fundamentalism.

Conserving moderation of religion at school can habituating students to uphold justice by respecting and respecting the opinions and choices of others, and balancing humanity and divinity. The Strategy for Strengthening Moderation has implications for: first, the emergence of students' moderate attitudes in realizing peaceful relations between people, having religion in diversity. Second, the emergence of mutual respect for each other, namely the tolerance of fellow students and students with the teacher. Third, the ability of students to filter information that leads to extremism-fundamentalism and exclusivity in schools.

\section{References}

A.Gani, Pendekatan Sufistik dalam Pendidikan Islam Berwawasan Perdamaian, Akademika, Vol.23, 2018 : 393.

Abdullah, Syamsuddin, Agama dan masyarakat, pendekatan Sosiologi Agama, Logos Wacana Ilmu, Ciputat, 1997 : 94.

Ahmad baso, Islam Nusantara, Ijtihad Jenius \& Ijma ' Ulama Indonesia Jilid I, Pustaka Afid, Tangerang Selatan, $2019: 1003$.

al-Bantani, Muhammad Nawawi, al-Futuhat al-Madaniyyah, (T.Th.), t.t., 21-22.

Ali Jumu'ah, Islam Wasathiyyah, https://www.wasathiyyah.com/karya/opini/23/01/2019/wasathiyy ah-apa-maksudnya/

Endraswara, Suwardi, Mistik Kejawen, Sinkretisme, Simbollisme dan Sufisme dalam Budaya Spiritual Jawa, Narasi, Jogyakarta, 2003 : 38-39. 
Fanani, Ahwan dan Tholhatul choir, ed. Islam dalam Berbagai Pembacaan Kontemporer, Pustaka Pelajar, Yogyakarta, 2009 : 277-278.

Hilmy Masdar, Cetak Biru Moderasi Beragama : Urgensi Panduan Normatif Aplikatif, Moderasi Beragama, dari Indonesia untuk Dunia, LKiS, Yogyakarta, 2019: 404.

Hilmy, Masdar. "Jalan Demokrasi Kita.",Intrans Publishing, Malang, $2016: 43$

Islamil, Faisal, NU Moderatisme dan Pluralisme, konstelasi dinamis keagamaan, kemasyarakatan dan keagamaan, IRCiSoD, Yogyakarta, $2020: 65$.

Kahmad, Dadang, Sosiologi Agama, Remaja Rosdakarya, Bandung, cet. Ke-5 2009 : 200.

Kemdikbud, Permendikbud No.20 Penguatan Pendidikan karakter pada SatuanPendidikan Formal, 2018

Kemdikbud., KBBI, https://kbbi.kemdikbud.go.id/moderasi, diakses pada tanggal 14 Maret 2020

Kementerian PPN/Bappenas, Bonus Demografi 2030-2040 : Strategi Indonesia Terkait Ketenagakerjaan dan Pendidikan, Siaran Pers, OECD, 2017, file PDF

Latif, Yudi. Negara Paripurna, Historisitas, Rasionalitas, dan Aktualitas Pancasila, PT Gramedia Pustaka Utama, Jakarta, 2012 : 118 .

Lickona, Thomas, Character Matters, Persoalan Karakter Bagaimana Membantu Anak Mengembangkan Penilaian yang Baik, Integritas, dan Kebajikan Penting Lainnya, Bumi aksara, Jakarta, 2016 : 16-17.

Lickona, Thomas, Educating for Character, Mendidik untuk membentuk Karakter, Bumi Aksara, Jakarta, 2016 : 101

Miles, Matthew B. \& AS. Michael Huberman, Analisis Data Kualitatif terj. Tjetjep Rohendi Rohidi, Jakarta: UI Press, 1992 :14.

Misrawi Zuhairi, Hadratussyaikh Hasyim Asy'ari Moderasi, Keutamaan, dan Kebangsaan, Jakarta: PT Kompas Media Nusantara, $2010: 13$. 
Muhajir, Afifuddin, Membangun Nalar Islam Moderat : kajian metodologis, Tanwirul Afkar, Situbondo, 2018 :24.

Muhibbin, Hakekat moderasi beragama, Moderasi Beragama dari Indonesia untuk Dunia, LKiS, Yogyakarta, 2019: 106.

1 Nasution, Harun. Teologi Islam : aliran-aliran sejarah analisa perbandingan, Universitas Indonesia, Jakarta, $2013: 3$.

Salamah, Islam dan tantangan Globalisasi : berbagai Paradigma Islam dalam menghadapi Globalisasi, Humanistika, 2019 : 51.

Saputro, Henri, The Counseling Way catatan tentang Konsepsi dan Ketrampilan Konseling, Deepublish, Yokyakarta, 2018 :48.

Shihab, M.Quraish, Wasathiyyah : wawasan Islam tentang moderasi beragama, Lentera Hati, Tangerang, $2019: 2$.

Siroj, Said Aqil, Tasawuf Sebagai Kritik Sosial: Mengedepankan Islam sebagai Inspirasi bukan Aspirasi, Bandung, Mizan :2006 : 35

Syam, Nur, Islam Nusantara Berkemajuan, Tantangan dan Upaya Moderasi Beragama, Fatwa Publishing, Semarang,2018 :107.

TGS. Saidurrahman, Penguatan Moderasi Islam Indonesia dan peranPTKIN, , Moderasi Beragama dari Indonesia untuk Dunia, (LKiS, Yogyakarta, 2019 : 35-37

Thohir. Muhammad, "Radikalisme Versus Pendidikan Agama Menggali Akar Radikalisme dari Kekerasan Terhadap Anak Atas Nama Pendidikan Agama.” Nadwa: Jurnal Pendidikan Islam, (2), 2015: 181. http://dx.doi.org/10.21580/nw.2015.9.2.521

Wahid, Madarzuki dan Rumi, Fiqh Madzhab Negara: Kritik atas Politik Hukum Islam di Indonesia, Yogyakarta, LKiS, 2011 :100.

Widodo, Arsip, "Moderation Of Islamic Education As An Effort To Prevent Radicalism (Case Study of FKUB Singkawang City, Kalimantan, Indonesia," Nadwa: Jurnal Pendidikan Islam, 13 (2), 2019. DOI : 10.21580/nw.2019.13.2.5086

Zainiyati, Husniyatus Salamah. "Learning Design of Citizenship Education in Indonesia after Ahok Tragedy, A Shaep of Social Media and Critical Literacy in Educational Process." Tarbuyatuna : JurnalPendidikan Islam, 2018: 52-71. 